\title{
MODELS OF FINANCIAL BEHAVIOR OF THE POPULATION IN THE CONDITIONS OF NANOECONOMICS (TAX ASPECT)
}

\author{
Natalia V. Gorshkova \\ Volgograd State University, Volgograd, Russian Federation \\ Victoria M. Ksenda \\ Volgograd State University, Volgograd, Russian Federation
}

\begin{abstract}
Modern economic science is developing dynamically under the influence of various factors. One of the new and relevant areas of economic research is nanoeconomics. Despite the relative novelty of this area of economic research, the foundations of theory and methodology have already been laid by a number of scientists. Nanoeconomics is defined as the individual's economy and allows us to consider the determinants of its development, including the behavioral aspects of the individual directly affecting his economic activity. In the framework of this approach, the study of the individual's financial behavior which directly affects the development of the financial system and the increase of country's competitiveness becomes particularly relevant. The application of the institutional approach allows expanding the classification of financial behavior strategies adding a new type of tax behavior, which is defined as the individual behavior (incentive, protest, adaptive) associated with the obligation to pay taxes and fees, as well as the right to use tax deductions (property, social, investment). The analysis of the market of financial services, performance indicators of financial institutions, as well as tax payments and deductions shows that citizens think about their financial well-being and depending on various factors (psychological, sociological, economic, political) their financial behavior changes, which is confirmed by the analysis of statistical indicators.
\end{abstract}

Key words: nanoeconomics, financial behavior, tax behavior, personal finance, savings.

Citation. Gorshkova N.V., Ksenda V.M. Models of Financial Behavior of the Population in the Conditions of Nanoeconomics (Tax Aspect). Journal of Volgograd State University. Economics, 2019, vol. 21, no. 4, pp. 207-218. (in Russian). DOI: https://doi.org/10.15688/ek.jvolsu.2019.4.20

УДК 336.01

ББК 65.26
Дата поступления статьи: 13.08.2019 Дата принятия статьи: 12.09.2019

\section{МОДЕЛИ ФИНАНСОВОГО ПОВЕДЕНИЯ НАСЕЛЕНИЯ В УСЛОВИЯХ НАНОЭКОНОМИКИ (НАЛОГОВЫЙ АСПЕКТ)}

\section{Наталья Валерьевна Горшкова}

Волгоградский государственный университет, г. Волгоград, Российская Федерация

Виктория Михайловна Ксенда

Волгоградский государственный университет, г. Волгоград, Российская Федерация

Аннотация. Современная экономическая наука динамично развивается под влиянием различных факторов. Одним из новых и актуальных направлений экономических исследований является наноэкономика. Несмотря на относительную новизну данного направления экономических исследований, основы его теории и методологии уже заложены рядом ученых. Наноэкономика определяется как экономика индивида и позволяет рассмотреть детерминанты ее развития, в том числе и поведенческие аспекты индивида, непосредственно влияющие на его экономическую деятельность. В рамках данного подхода особо актуальным 
становится изучение финансового поведения индивида, которое непосредственным образом влияет на развитие финансовой системы и повышение конкурентоспособности страны. Применение институционального подхода позволило расширить классификацию стратегий финансового поведения, дополнив ее новым видом - налоговым, который определяется как поведение индивида (побудительное, протестное, адаптивное), связанное с обязанностью уплаты налогов и сборов, а также с правом пользования налоговыми вычетами (имущественными, социальными, инвестиционными). Проведенный анализ рынка финансовых услуг, показателей деятельности финансовых институтов, а также налоговых платежей и вычетов показал, что граждане задумываются о своем финансовом благосостоянии и в зависимости от различных факторов (психологических, социологических, экономических, политических) их финансовое поведение меняется, что подтверждается анализом статистических показателей.

Ключевые слова: наноэкономика, финансовое поведение, налоговое поведение, личные финансы, сбережения.

Цитирование. Горшкова Н. В., Ксенда В. М. Модели финансового поведения населения в условиях наноэкономики (налоговый аспект) // Вестник Волгоградского государственного университета. Экономика. -2019. - Т. 21, № 4. - С. 207-218. - DOI: https://doi.org/10.15688/ek.jvolsu.2019.4.20

\section{Введение}

Современные экономические исследования перманентно расширяются и дополняются фундаментальными понятиями в соответствии с текущим развитием хозяйственно-экономической жизни общества. Практически происходящие процессы глобализации и информатизации экономики, применение уровневого подхода в экономических исследованиях развили экономическую теорию и дополнили ее новым понятием, а глобальную экономическую систему - новым уровнем, называемым «наноэкономика», существующим наряду с макро-, мега-, мезоэкономикой.

Обращаясь к исследованиям в научной литературе, можно встретить различные трактовки данного понятия. Первые исследования наноэкономики в российской экономической науке принадлежат Г.Б. Клейнеру, который изначально определил ее как «экономику физических лиц», а позже расширил причинно-следственные связи, основанные на поведенческих настроениях индивида [Клейнер, 2004]. Впоследствии фундаментальные исследования развития теории и методологии наноэкономики принадлежат О.В. Иншакову, который определил ее осмысление в следующих течениях: утилитаристском, бихевиористском, институциональном и экогенетическом (эволюционистском) [Иншаков, 2007].

По-нашему мнению, именно второе направление исследования наноэкономики носит мультидисциплинарный характер и позволяет изучать поведение индивидов (физических лиц, граждан) посредством исследования финансово-экономических отношений и взаимосвязей. Кроме того, позволяет исследовать институциональную основу государственного воздействия на распределение ресурсов (потребление, сбережение и инвестирование) населения, развитие индивидуального предпринимательства.

Развитие теории наноэкономики, как полагает И.А. Гришин, и с этим следует согласиться, «...будет происходить в условиях построения многомерной модели, в центре которой индивид, изучающий окружающую действительность и осознающий закономерности ее развития, что будет определять его экономическую деятельность с оценкой собственной удовлетворенности в результате» [Гришин, 2012].

\section{Результаты исследования}

Одной из основных детерминант индивидуальной экономической деятельности является финансовое поведение. Изучение исследований, посвященных сущности финансового поведения (табл. 1), позволило сформировать собственное видение дефиниции «финансовое поведение».

В результате мы определяем финансовое поведение индивида как процесс привлечения и распоряжения (перераспределения) имеющихся финансовых ресурсов, обусловленный его субъективным внутренним восприятием экономической действительности и иными субъективными и объективными факторами, с целью расширенного потребления, улучшения качества жизни и получения дополнительного дохода. 
Авторские подходы к определению финансового поведения

\begin{tabular}{|l|l|}
\hline И.А. Алиева & $\begin{array}{l}\text { «...Деятельность домохозяйств по поводу мобилизации и использования денежных } \\
\text { средств. Особая разновидность экономического поведения, связанная с поведением } \\
\text { населения на рынке финансовых продуктов и услуг и предполагающая мобилизацию, } \\
\text { перераспределение и инвестирование имеющихся в распоряжении населения денеж- } \\
\text { ных ресурсов...» }\end{array}$ \\
\hline Е.В. Галишникова & $\begin{array}{l}\text { «..Поведение домохозяйств и индивидов, связанное с получением и расходованием } \\
\text { денежных средств...» }\end{array}$ \\
\hline Н.Ю. Гондик & $\begin{array}{l}\text { «..Поведение населения, которое непосредственно связано с перераспределением и } \\
\text { инвестированием денежных ресурсов...» }\end{array}$ \\
\hline А.И. Петенева & $\begin{array}{l}\text { «..Финансовое поведение основывается на рациональном выборе из существующих } \\
\text { вариантов распоряжения финансовыми ресурсами с целью минимизации потерь и из- } \\
\text { влечения максимальных выгод, проявляется у населения как экономический механизм } \\
\text { приспособления к меняющейся экономической обстановке...» }\end{array}$ \\
\hline А.И. Фатихов & $\begin{array}{l}\text { «..Деятельность индивидов, социальных групп и сообществ для достижения общих и } \\
\text { личных целей, направленных на удовлетворение собственных потребностей через ис- } \\
\text { пользование финансовых ресурсов при взаимодействии между собой и финансовыми } \\
\text { институтами...» }\end{array}$ \\
\hline
\end{tabular}

Примечание. Составлено авторами по: [Алиева, 2016; Галишников, 2012; Гондик, 2014; Петенева, 2018; Фатихов, 2010].

Совокупность факторов, влияющих на финансовое поведение, неограниченна. К ним, в частности, относятся: психологические, социальные, экономические, политические, инфраструктурные, институциональные, демографические, этнокультурные и др. Влияние общности этих факторов сводится к рациональной, нерациональной или иррациональной моделям финансового поведения, а изменение объемов распределения личных финансовых ресурсов населения можно рассматривать в качестве индикатора, характеризующего социальноэкономическое развитие, а также уровень жизни граждан.

Современные исследования, посвященные изучению финансового поведения, рассматривают отдельные стратегии, ориентированные на рыночные условия предлагаемых финансовых услуг, а именно:

- потребительскую (расходование фактических финансовых ресурсов на текущие нужды);

- сберегательную (изъятие части финансовых средств из личного финансового оборота и их сохранение);

- инвестиционно-накопительную (вложение накопленных / временно свободных или изъятие текущих финансовых ресурсов с целью получения прибыли или дохода от их использования);
- кредитную (пользование кредитными продуктами на расширенное потребление благ ввиду отсутствия необходимых для этого финансовых ресурсов);

- страховую (сокращение риска путем передачи части финансовых ресурсов страховщику на основе договора страхования с целью защиты от возможных негативных факторов);

- пенсионную (обеспечение более достойных условий и качества жизни после выхода на пенсию посредством формирования финансовых средств на счетах в пенсионных фондах). Страховое и пенсионное поведение наименее развито и доступно более ограниченному кругу индивидов, поскольку предполагает определенные затраты, обусловленные вложением свободных ресурсов, которые не у каждого имеются в наличии, и риском недостижения предполагаемого результата.

Данные стратегии финансового поведения отражают финансово-экономические отношения граждан с финансовыми институтами: коммерческими банками, кредитными организациями, инвестиционными фондами, страховыми организациями, пенсионными фондами, - но не затрагивают формальные финансово-экономические отношения.

Основываясь на имеющихся исследованиях личных финансов и финансового поведения граждан, считаем необходимым расширить его понятием «налоговое поведение» (рис. 1). 


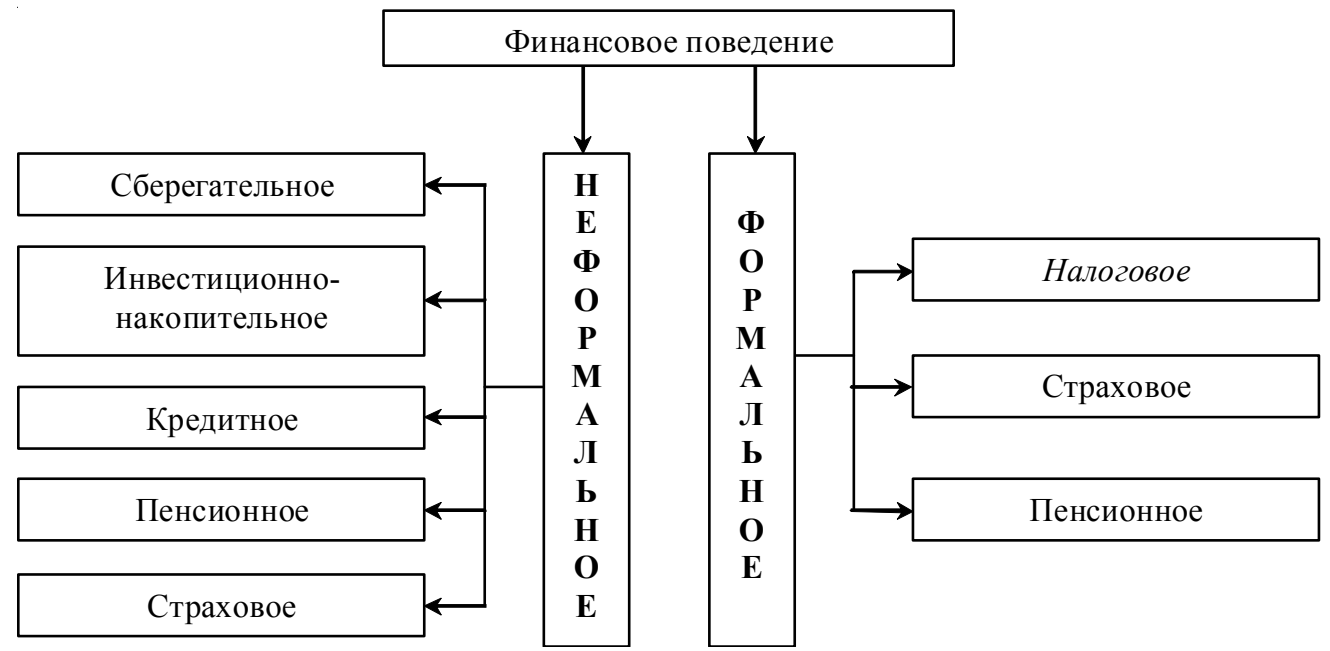

Рис. 1. Стратегии финансового поведения в рамках институционального подхода Примечание. Составлено авторами.

Налоговое поведение исследуется в научной литературе. Так, А.С. Адвокатова рассматривает понятия «модель поведения», «модель налогового контроля», «модель взаимоотношений налогоплательщиков и налоговых органов» и приводит следующую классификацию моделей поведения налогоплательщиков: «...активная [(рациональная (альтернативная)], агрессивная; пассивная (риск-нейтральная; дискретная)». Однако автор раскрывает сущность только активной модели (нацелена на оптимизацию налоговых платежей) и пассивной (в результате злоупотребления правом, несовершенства налогового законодательства налогоплательщики стремятся снизить налоговые платежи или исключить их) [Адвокатова, 2017].

А.В. Галухин считает, что «...наряду с трудовым, кредитным, потребительским поведением налоговое является составляющим экономического поведения и связано с уплатой обязательных платежей в бюджет и взаимодействием налогоплательщика с налоговыми органами». Классификация моделей поведения этого автора основана на инструментах налогового менеджмента и определяется как: уклонение от уплаты налогов, обход налогов (законный - правомерное поведение, незаконный - противоправное поведение), налоговое планирование, уплата налогов без специальных мер их снижения. Данная концепция также предполагает общий подход к налогоплательщикам. Однако научный инте- рес представляет авторская классификация поведения налогоплательщиков: добровольно выполняющие налоговые обязательства, неосведомленные, халатные и уклоняющиеся от исполнения обязанности по уплате налога [Галухин, 2019].

В.С. Мартынова определяет налоговое поведение как «...специфическую форму экономических отношений государства с хозяйствующими субъектами, от чего зависит количество поступлений в государственный бюджет и благосостояние страны в целом». При этом классификация представлена адекватным налоговым поведением: комфортным и правильным поведением; и неадекватным - ошибочным и нестандартным поведением. Ошибочное и комфортное поведение направлены в противоположную сторону от поставленной индивидом цели, а правильное и нестандартное - к достижению обозначенной цели. Такая авторская концепция имеет право существовать, однако автор не раскрывает детального содержания такого поведения и не уточняет цели индивида [Мартынова, 2018].

Е.С. Вылкова и А.Л. Тарасевич не дают определения налоговому поведению, но приводят различные авторские интерпретации «...от грамотного управления налогообложением (стандартные методы налогообложения, налоговое планирование, налоговый менеджмент) до уклонения от уплаты налогов». При этом представленная данными автора- 
Н.В. Горикова, В.М. Ксенда. Модели финансового поведения населения в условиях наноэкономики

ми классификация основана на биологических моделях поведения (симбиоз, конкуренция, паразитизм) и теории игр (Выигрыш Выигрыш, Проигрыш - Выигрыш, Выигрыш - Проигрыш, Проигрыш - Проигрыш). В результате пересечение интересов налогоплательщика и государства приводит к налоговому симбиозу, налоговому эгоизму налогоплательщика, налоговому эгоизму государства и налоговому противостоянию. Модели поведения неплоские, они многомерны, поскольку охватывают значительное число участников налоговых отношений [Вылкова и др., 2017].

В целом все исследователи формулируют собственное авторское видение и модели налогового поведения, эти модели относятся непосредственно к процессу налогообложения и охватывают всех налогоплательщиков: и население, и организации. В рамках исследования финансового поведения индивида в наноэкономике считаем возможным определить налоговое поведение индивида как осознанные действия налогоплательщика - физического лица, направленные на исполнение (неисполнение) обязанности по уплате налога, исходя из его жизненных целеполаганий, психотипа, уровня социальной ответственности и финансовой грамотности. Исходя из факторов, влияющих на налоговое поведение, считаем, что оно может быть (рис. 2):

- побудительно-компромиссным (индивид принимает уплату налога как безуслов- ную необходимость и осознает вменяемую ему обязанность по его уплате);

- протестно-игнорирующим (девиантным или оппортунистическим) (индивид принципиально не согласен с вменяемой обязанностью уплаты налогов и игнорирует предпринимаемые администраторами налогов побуждающие мероприятия для его уплаты);

- адаптивно-инициативным (индивид безусловно принимает вменяемую ему обязанность по уплате налога и активно пользуется правом применения налоговых вычетов по мере их возникновения).

Кроме того, налоговое поведение может являться как производным от имеющихся стратегий финансового поведения, так и прямым. Прямое налоговое поведение исходит из самой сущности налога и обязывает индивида уплачивать установленные законом налоги и сборы, тогда налоговое поведение проявляется как побудительно-компромиссное. При этом, если гражданин недобросовестен, он будет стремиться уклониться от уплаты налогов и сборов, скрывая свой доход, который может быть связан, например, либо с его предпринимательской деятельностью, либо со сдачей имущества в аренду. Уклоняясь от уплаты налогов, индивид сокращает поступление налогов и сборов в бюджетную систему, подвергается риску возникновения налоговой задолженности и, как следствие, административной и уголовной ответственности, что особенно важно для оценки его налогового поведения.

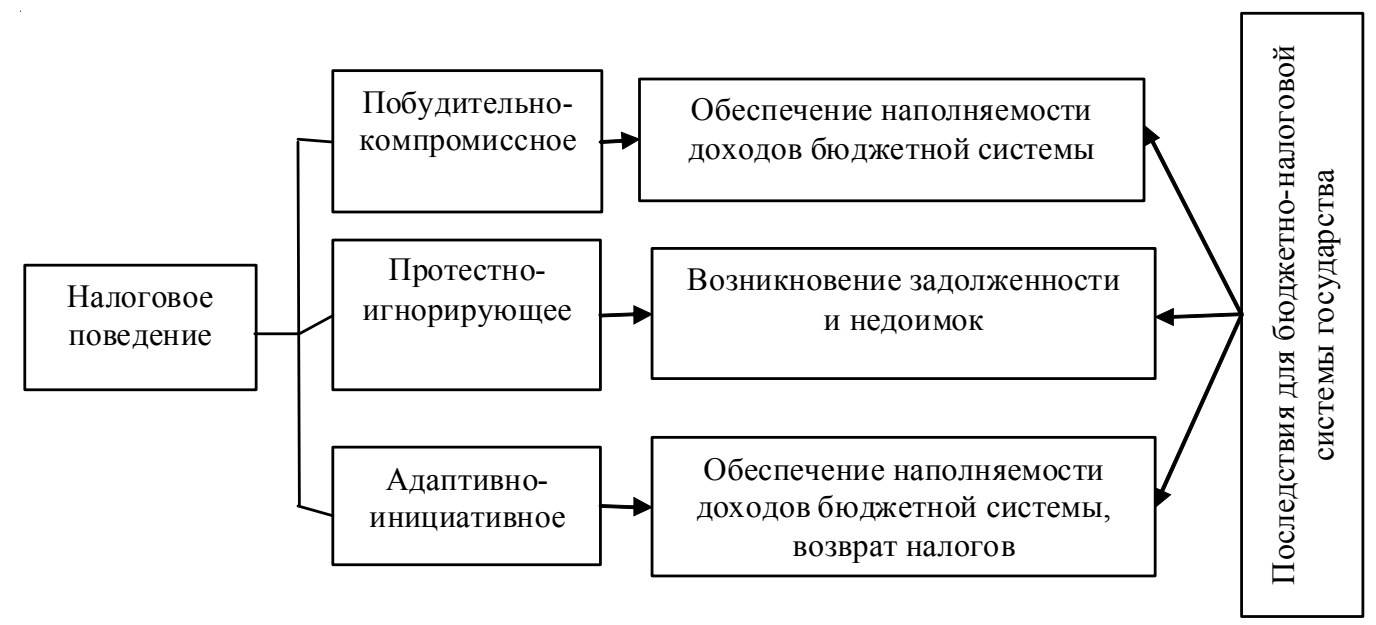

Рис. 2. Типы налогового поведения индивида и его финансовые последствия

Примечание. Составлено авторами. 
Производное налоговое поведение заключается в следующем. Например, принимая решение о том, чтобы воспользоваться займом или кредитом (ипотечным кредитом на приобретение жилья), поучаствовать в программах пенсионного обеспечения, инвестировать свободные денежные ресурсы, гражданин имеет право на получение:

1) имущественного налогового вычета: предоставляется в сумме, которая фактически израсходована им на погашение процентов по целевым займам (кредитам), а также на новое строительство или приобретение жилых домов, квартир, комнат или долей в них;

2) социального налогового вычета: предоставляется в результате уплаты дополнительных страховых взносов на накопительную часть пенсии; пенсионных взносов по договорам негосударственного пенсионного обеспечения, которые заключены с негосударственным пенсионным фондом; страховых взносов по договору добровольного пенсионного страхования; страховых взносов по договору страхования жизни, который заключен со страховой организацией, в свою пользу или в пользу членов семьи;

3) инвестиционного налогового вычета: предоставляется в размере положительного финансового результата, который может быть получен от реализации (погашения) ценных бумаг; в сумме денежных средств, внесенных на индивидуальный инвестиционный счет; в сумме положительного финансового результата, полученного по операциям на индивидуальном инвестиционном счете.
$\mathrm{C}$ точки зрения психологии любые сбережения, накопления, платежи по кредитам и даже уплату налогов и сборов граждане рассматривают как расходы. Предоставляя налоговые вычеты, государство, с одной стороны, стимулирует финансовую активность населения, с другой - позволяет сократить расходы на кредитные, инвестиционные, пенсионные программы.

Далее проведем анализ структуры денежных доходов, расходов и направлений финансового поведения граждан. Согласно опросу, проведенному 14 июля 2019 г. Фондом общественного мнения, о материальном положении населения (1 500 респондентов - граждан РФ от 18 лет и старшев в 53 субъектах РФ, в 104 населенных пунктах), 8 \% его участников считают, что материальное положение семьи улучшилось за последние месяцы, $24 \%$ - ухудшилось, $67 \%$ - изменения отсутствуют. Полагают, что в ближайшем году материальная ситуация улучшится, $-22 \%$ опрошенных, ухудшится - $18 \%$, не ждут изменений $39 \%$, а совсем не знают, что будет, $-21 \%$. При этом на вопрос: «Какое высказывание точнее всего описывает материальное положение вашей семьи?» - были даны следующие ответы (табл. 2). В последние годы заметно увеличилось число ответов - «На автомобиль хватает» и сократилось - «На одежду хватает, на крупную бытовую технику - нет».

По оценкам Росстата, в 2018 г. по сравнению с 2017 г. реальные располагаемые денежные доходы населения Российской Федерации (доходы за вычетом обязательных платежей,

Таблийа 2

Результаты опроса населения: «Какое высказывание точнее всего описывает материальное положение вашей семьи?»

\begin{tabular}{|l|c|c|c|c|c|c|c|c|c|}
\hline \multicolumn{1}{|c|}{ Ответ } & \multicolumn{9}{|c|}{ Период } \\
\cline { 2 - 11 } & 2010 г. & 2011 г. & 2012 г. & 2013 г. & 2014 г. & 2015 г. & 2016 г. & 2017 г. & 2018 г. \\
\hline $\begin{array}{l}\text { Денег не хватает на пи- } \\
\text { тание }\end{array}$ & $\mathbf{1 4}$ & 15 & 13 & 10 & $\mathbf{9}$ & 11 & 13 & 12 & 12 \\
\hline $\begin{array}{l}\text { На питание хватает, на } \\
\text { одежду - нет }\end{array}$ & $\mathbf{2 9}$ & 27 & 26 & 24 & $\mathbf{2 3}$ & 27 & 28 & 27 & 25 \\
\hline $\begin{array}{l}\text { На одежду хватает, на } \\
\text { крупную бытовую тех- } \\
\text { нику -нет }\end{array}$ & 39 & 39 & 40 & 42 & $\mathbf{4 4}$ & 41 & 36 & 35 & $\mathbf{3 4}$ \\
\hline $\begin{array}{l}\text { На бытовую технику } \\
\text { хватает, на автомо- } \\
\text { биль-нет }\end{array}$ & $\mathbf{1 3}$ & 15 & 16 & 18 & $\mathbf{1 9}$ & 16 & 16 & 17 & 18 \\
\hline На автомобиль хватает & 4 & 4 & 5 & 5 & 5 & 5 & 8 & 9 & $\mathbf{1 0}$ \\
\hline
\end{tabular}

Примечание. Источник: [Фонд...]. 
Н.В. Горшкова, B.M. Ксенда. Модели финансового поведения населения в условиях наноэкономики

скорректированные на индекс потребительских цен) увеличились на 0,3 \% и составили в расчете на душу населения 32635 руб. в месяц.

При этом в структуре денежных доходов населения в 2018 г. по сравнению с соответствующим периодом 2017 г. возросла доля оплаты труда (включая скрытую заработную плату) при снижении доли социальных выплат, доходов от собственности и доходов от предпринимательской деятельности (табл. 3).
При этом в структуре использования денежных доходов населения Российской Федерации наблюдается увеличение расходов на покупку товаров и оплату услуг $(1,2 \%)$, обязательные платежи и разнообразные взносы $(1,1 \%)$, а сбережения сократились на 2,5 \% (табл. 4).

Опрос населения по измерению инфляционных ожиданий и потребительских настроений, проводимый Банком России [Центральный банк...], показал: более половины опро-

\section{Структура денежных доходов населения Российской Федерации в 2010-2018 гг.}

\begin{tabular}{|l|c|c|c|c|c|c|c|c|c|}
\hline \multicolumn{1}{|c|}{ Показатель } & \multicolumn{9}{|c|}{ Период } \\
\cline { 2 - 9 } & 2010 г. & 2011 г. & 2012 г. & 2013 г. & 2014 г. & 2015 г. & 2016 г. & 2017 г. & 2018 г. \\
\hline $\begin{array}{l}\text { Всего денеж- } \\
\text { ных доходов, } \\
\text { млрд рублей }\end{array}$ & 32498,3 & 35648,7 & 39903,7 & 44650,4 & 47920,6 & 43525,9 & 53991,0 & 55272,1 & 57456,5 \\
\hline $\begin{array}{l}\text { В том числе, \%: } \\
\text { оплата труда, } \\
\text { включая } \\
\text { скрытую зар- } \\
\text { плату }\end{array}$ & 65,2 & 65,6 & $\mathbf{6 5 , 1}$ & 65,3 & 65,8 & 65,6 & 64,7 & 65,3 & $\mathbf{6 6 , 2}$ \\
\hline $\begin{array}{l}\text { доходы от } \\
\text { предпринима- } \\
\text { тельской дея- } \\
\text { тельности }\end{array}$ & 8,9 & 8,9 & $\mathbf{9 , 4}$ & 8,6 & 8,4 & 7,9 & 7,8 & 7,7 & $\mathbf{7 , 5}$ \\
\hline $\begin{array}{l}\text { социальные } \\
\text { выплаты }\end{array}$ & $\mathbf{1 7 , 7}$ & 18,3 & 18,4 & 18,6 & 18,0 & 18,3 & 19,0 & $\mathbf{1 9 , 6}$ & 19,4 \\
\hline $\begin{array}{l}\text { доходы от } \\
\text { собственности }\end{array}$ & 6,2 & 5,2 & 5,1 & 5,5 & 5,8 & 6,2 & $\mathbf{6 , 5}$ & 5,4 & $\mathbf{4 , 9}$ \\
\hline $\begin{array}{l}\text { другие дохо- } \\
\text { ды }\end{array}$ & 2,0 & 2,0 & 2,0 & 2,0 & 2,0 & 2,0 & 2,0 & 2,0 & 2,0 \\
\hline
\end{tabular}

Примечание. Источник: [Федеральная служба...].

Таблицуа 4

\section{Структура использования денежных доходов населения в Российской Федерации} в 2010-2018 гг.

\begin{tabular}{|c|c|c|c|c|c|c|c|c|c|}
\hline \multirow{2}{*}{ Показатель } & \multicolumn{9}{|c|}{ Период } \\
\hline & 2010 г. & 2011 г. & 2012 г. & 2013 г. & 2014 г. & 2015 г. & 2016 г. & 2017 г. & 2018 г. \\
\hline $\begin{array}{l}\text { Всего денежных } \\
\text { расходов, } \\
\text { рублей }\end{array}$ & н. Д. & н. Д. & н. Д. & 42329,5 & 46023,1 & 48336,3 & 49566,2 & 52125,8 & 56011,3 \\
\hline $\begin{array}{l}\text { Всего денежных } \\
\text { доходов, \%. }\end{array}$ & 100 & 100 & 100 & 100 & 100 & 100 & 100 & 100 & 100 \\
\hline $\begin{array}{l}\text { В том числе, \%: } \\
\text { покупка товаров } \\
\text { и оплата услуг }\end{array}$ & 69,6 & 73,5 & 74,2 & 73,6 & 75,3 & 71,0 & 73,1 & 75,8 & $\mathbf{7 7 , 0}$ \\
\hline $\begin{array}{l}\text { рбязательные } \\
\text { платежи и разно- } \\
\text { образные взносы }\end{array}$ & 9,7 & 10,3 & 11,1 & 11,7 & 11,8 & 10,9 & 11,2 & 11,1 & 12,2 \\
\hline сбережения & 14,8 & 10,4 & 9,9 & 9,8 & 6,9 & 14,3 & 11,1 & 8,1 & 5,6 \\
\hline покупка валюты & 3,6 & 4,2 & 4,8 & 4,2 & 5,8 & 4,2 & 4,0 & 3,7 & 3,7 \\
\hline $\begin{array}{l}\text { прирост (умень- } \\
\text { шение) денег на } \\
\text { руках у населения }\end{array}$ & 2,3 & 1,6 & 0,0 & 0,7 & 0,2 & $-0,4$ & 0,6 & 1,3 & 1,5 \\
\hline
\end{tabular}

Примечание. Источник: [Федеральная служба...]. 
шенных полагают, что необходимо откладывать свободные деньги; около 30 \% полагают, что необходимо покупать крупные дорогостоящие товары, при этом около 40 \% считают, что сбережения лучше хранить на счетах в банке или наличной форме.

На изменение финансового поведения прямо влияет складывающаяся экономическая ситуация. Так, 2014 г. характеризовался снижением розничного кредитования (ипотечного и потребительского). Личное восприятие гражданами экономической ситуации повлияло на увеличение сбережений и накоплений (табл. 5).

По данным Рейтингового агентства «Эксперт РА» [Рейтинговое агентство...] в
2018 г. кредитная активность следующая. Выдачи ипотеки выросли на 49 \% и достигли рекордного объема - 3 трлн рублей. Способствовали таким показателям: отложенный спрос на жилье; низкие процентные ставки по ипотеке; относительно стабильные цены на недвижимость. Большой спрос на ипотечные кредиты приходился на кредиты с первоначальным взносом менее $20 \%$ (в 2018 г. их доля составила $45 \%$ - выросла на $7 \%$ ). Снижение суммы первоначального взноса и относительно невысокие ставки способствовали росту среднего размера ипотечного кредита. Однако сроки кредитования в 2018 г. увеличились - до 16,7 лет (в среднем более чем на 1 год).

\section{Структура и динамика сбережений населения в Российской Федерации}

Таблица 5 в 2010-2018 гг.

\begin{tabular}{|c|c|c|c|c|c|c|}
\hline \multirow{2}{*}{ Показатель } & \multicolumn{6}{|c|}{ Период } \\
\hline & 2013 г. & 2014 г. & 2015 г. & 2016 г. & 2017 г. & 2018 г. \\
\hline $\begin{array}{l}\text { Прирост (уменьшение) сбережений во } \\
\text { вкладах банков резидентов и нерезидентов: } \\
\text { - млрд руб.; } \\
\text { - \% }\end{array}$ & $\begin{array}{c}2632,4 \\
6,0\end{array}$ & $\begin{array}{l}-129 \\
-0,3\end{array}$ & $\begin{array}{c}3058,6 \\
5,8\end{array}$ & $\begin{array}{c}271,5 \\
4,2\end{array}$ & $\begin{array}{c}2305,5 \\
4,1\end{array}$ & $\begin{array}{c}1818,8 \\
3,1\end{array}$ \\
\hline $\begin{array}{l}\text { Приобретение государственных и других } \\
\text { ценных бумаг: } \\
\text { - млрд руб.; } \\
\text { - \% }\end{array}$ & $\begin{array}{l}223 \\
0,5\end{array}$ & $\begin{array}{c}250 \\
0,5\end{array}$ & $\begin{array}{l}272 \\
0,1\end{array}$ & $\begin{array}{l}34 \\
0,1\end{array}$ & $\begin{array}{l}38 \\
0,1\end{array}$ & $\begin{array}{c}-82 \\
-0,1\end{array}$ \\
\hline $\begin{array}{l}\text { Прирост (уменьшение) средств на счетах } \\
\text { индивидуальных предпринимателей: } \\
\text { - млрд руб.; } \\
\text { - \% }\end{array}$ & $\begin{array}{l}20 \\
0,0\end{array}$ & $\begin{array}{l}44 \\
0,1\end{array}$ & $\begin{array}{l}30 \\
0,1\end{array}$ & $\begin{array}{l}63 \\
0,1\end{array}$ & $\begin{array}{l}128 \\
0,2\end{array}$ & $\begin{array}{l}138 \\
0,2\end{array}$ \\
\hline $\begin{array}{l}\text { Прирост (уменьшение) наличных денег у } \\
\text { населения в инвалюте: } \\
\text { - млрд руб.; } \\
\text { - \% }\end{array}$ & $\begin{array}{l}254 \\
0,6\end{array}$ & $\begin{array}{c}1130,5 \\
2,4\end{array}$ & $\begin{array}{l}-530 \\
-1,0\end{array}$ & $\begin{array}{c}1126,2 \\
2,1\end{array}$ & $\begin{array}{c}1237,7 \\
2,2\end{array}$ & $\begin{array}{c}1391,1 \\
2,4\end{array}$ \\
\hline $\begin{array}{l}\text { Расходы на покупку недвижимости: } \\
\text { - млрд руб.; } \\
\text { - \% }\end{array}$ & $\begin{array}{l}929 \\
2,1 \\
\end{array}$ & $\begin{array}{c}1052,8 \\
2,2\end{array}$ & $\begin{array}{r}891 \\
1,7 \\
\end{array}$ & $\begin{array}{c}1117,0 \\
2,1\end{array}$ & $\begin{array}{c}1119,1 \\
2,0\end{array}$ & $\begin{array}{c}1166,0 \\
2,0\end{array}$ \\
\hline $\begin{array}{l}\text { Покупка населением и крестьянскими } \\
\text { (фермерскими) хозяйствами скота и птицы: } \\
\text { - млрд руб.; } \\
\text { - \% }\end{array}$ & $\begin{array}{l}105 \\
0,2\end{array}$ & $\begin{array}{l}110 \\
0,2\end{array}$ & $\begin{array}{l}121 \\
0,2\end{array}$ & $\begin{array}{l}124 \\
0,2\end{array}$ & $\begin{array}{l}128 \\
0,2\end{array}$ & $\begin{array}{l}159 \\
0,3\end{array}$ \\
\hline $\begin{array}{l}\text { Прирост (уменьшение) задолженности по } \\
\text { кредитам: } \\
\text { - млрд руб.; } \\
\text { - \% }\end{array}$ & $\begin{array}{c}2289,5 \\
5,2\end{array}$ & $\begin{array}{c}1229,9 \\
2,6\end{array}$ & $\begin{array}{l}-902 \\
-1,7\end{array}$ & $\begin{array}{l}95 \\
0,2\end{array}$ & $\begin{array}{c}1356,7 \\
2,4\end{array}$ & $\begin{array}{c}2725,9 \\
4,7\end{array}$ \\
\hline $\begin{array}{l}\text { Прочие сбережения: } \\
\text { - млрд руб.; } \\
\text { - \% }\end{array}$ & $\begin{array}{l}25 \\
0,1\end{array}$ & $\begin{array}{l}57 \\
0,1 \\
\end{array}$ & $\begin{array}{l}69 \\
0,1 \\
\end{array}$ & $\begin{array}{l}118 \\
0,2\end{array}$ & $\begin{array}{r}211 \\
0,4 \\
\end{array}$ & $\begin{array}{l}286 \\
0,5\end{array}$ \\
\hline $\begin{array}{l}\text { Всего прирост сбережений населения: } \\
\text { - млрд руб.; } \\
\text { - \% }\end{array}$ & $\begin{array}{c}1901,2 \\
4,3\end{array}$ & $\begin{array}{c}1286,1 \\
2,7\end{array}$ & $\begin{array}{c}4816,8 \\
9,1\end{array}$ & $\begin{array}{c}4759,1 \\
8,7\end{array}$ & $\begin{array}{c}3812,5 \\
6,8\end{array}$ & $\begin{array}{c}2151,1 \\
3,7\end{array}$ \\
\hline
\end{tabular}

Примечание. Источник: [Федеральная служба...]. 
По данным Агентства по страхованию вкладов (АСВ) [Агентство...] инвестиционносберегательная активность населения продемонстрировала положительные результаты: рост вкладов населения в банках в 2018 г. составил $6,5 \%$ (в 2017 г. - 10,7 \%), увеличившись на 2473 млрд руб. до 28460 млрд рублей. Большой прирост вкладов населения приходится на конец года, что обусловлено выплатами премий и иных дополнительных вознаграждений в связи с предстоящими новогодними праздниками.

В 2018 г. выросли крупные вклады. Так, вклады от 1,4 млн до 3 млн руб. выросли на $17,8 \%$ по сумме и на $18,2 \%$ по количеству счетов, вклады свыше 3 млн руб. выросли на $15,1 \%$ по сумме и на $17,6 \%$ по количеству счетов. На $8,5 \%$ и на $2,4 \%$ по количеству счетов увеличились вклады до 100 тыс. рублей. Выросли на 6,2 \% и 11,1 \% по сумме вклады от 100 тыс. до 1 млн руб. и на 5,3\% по сумме и $11,0 \%$ по количеству счетов - вклады от 1 млн до 1,4 млн рублей.

Средний размер вклада по банковской системе (без учета счетов менее 1 тыс. руб.) составил 166,0 тыс. рублей.

В 2018 г. доля краткосрочных (до 1 года) вкладов снизилась с 37,8 до $36,9 \%$, долгосрочных (свыше 1 года) - с 41,2 до 39,5 \%. Доля вкладов до востребования увеличилась с 21,0 до 23,6\%.

Если оценивать по имеющимся данным инвестиционно-сберегательное поведение населения, то оно демонстрирует положительную динамику, причем активное увеличение крупных вкладов свидетельствует о том, что вкладывают в основном люди с уровнем доходов выше среднего.

Что касается результатов страхового поведения граждан, то, по данным Банка России, рост страхового рынка в 2018 г. обеспечивался в основном личным страхованием (его доля составила более половины - 54 \% от объема премий). Страхование жизни заняло основную долю (из 201 млрд руб. прироста премий 121 млрд руб. - прирост на 15,7 \%), страхование от несчастных случаев 48,3 млрд руб., добровольное медицинское страхование - 11,8 млрд рублей.

Структура страхового рынка изменилась как по источнику продаж, так и по видам стра- хования. Розничные продажи через банки значительно опережают другие источники и вытесняют их, более половины посреднических продаж приходится именно на них. Объем премий, полученных с помощью кредитных организаций, вырос на 156,5 млрд руб. при общем росте продаж через посредников на 135 млрд рублей. Интернет-страхование развито благодаря е-ОСАГО, но в розничных видах его потенциал предполагает многократный темп роста в ближайшие 2-3 года. Реализация страховых полисов через агентов потеряла в 2018 г. 37,5 млрд премий, и прогнозируется, что такая тенденция будет сохраняться.

За 2018 г. число участников добровольной пенсионной системы увеличилось на 2,1 \%, до 6,1 млн человек. Размер среднего счета одного застрахованного лица за 2018 г. вырос на 5,7 \% и достиг 186,1 тыс. рублей.

Что касается налогового поведения граждан, то оно характеризуется показателями поступлений в бюджетную систему налога на доходы физических лиц, имущественных налогов (транспортный налог, земельный налог, налог на имущество физических лиц) и получением налоговых вычетов на основе налоговых деклараций, представленных в налоговый орган. Так, по данным ФНС России в 2018 г. подано 9 млн деклараций, что на $6 \%$ выше показателя 2017 года. На 10,5 \% увеличилась сумма налога, подлежащая уплате, и составила 90,8 млрд рублей. На 17 \% увеличилась сумма налога, заявленная к возврату из бюджета (в том числе в связи с предоставлением налоговых вычетов), и составила 173,6 млрд руб. - больше, чем в 2017 году. Как отмечает ФНС России, «...рост данных показателей связан, в том числе, с работой налоговых органов, направленных на повышение налоговой грамотности населения, информирование о возможных льготах и упрощение процедуры предоставления налоговых вычетов».

Среди физических лиц самыми востребованными налоговыми вычетами являются имущественные и социальные. Свыше 1,5 млн граждан обратились в налоговые органы за предоставлением социальных вычетов в 2018 г., чаще всего налогоплательщики заявляли имущественные вычеты на покупку жилья - 3,6 млн физических лиц подали документы для их получения на общую сумму 
1,2 трлн рублей. Растет востребованность инвестиционного налогового вычета на сумму ежегодного взноса на индивидуальный инвестиционный счет. За период 2015-2017 гг. инвестиционные налоговые вычеты продемонстрировали опережающий рост. Количество налогоплательщиков, заявляющих вычет при использовании индивидуального инвестиционного счета, выросло в 4 раза (с 8666 чел. в 2015 г. до 42945 чел.) (рис. 3), а возмещаемые суммы - в 5 раз.

Анализ данных об использовании налоговых вычетов позволяет сделать вывод об активном налоговом поведении граждан, растет как их количество, так и суммы предоставления налоговых вычетов.

\section{Выводы}

Таким образом, наноэкономика - сформировавшаяся область экономических исследований. В центре ее изучения - поведение индивида, которое формирует ощущение окружа- ющей действительности, определяет задачи, стимулы и мотивацию, источники информации - основу его экономической деятельности. Финансовое поведение определяется источниками (финансовыми ресурсами), факторами (эндогенными и экзогенными, объективными и субъективными), рыночными условиями (сложившейся экономической ситуацией, действующими финансовыми институтами) и институциональными ограничениями (обязательными нормами). Исследование всей совокупности этих условий позволило сформировать модель (тип, стратегию) финансового поведения индивида в условиях наноэкономики - налоговую, существующую наряду со сберегательной, инвестиционно-накопительной, кредитной, страховой и пенсионной моделями. Анализ структуры доходов и расходов граждан, их ожиданий и предположений, а также показателей банковской, страховой, пенсионной и налоговой систем, отражающих факт участия граждан, показал их активное финансовое поведение, быстро реагирующее на из-

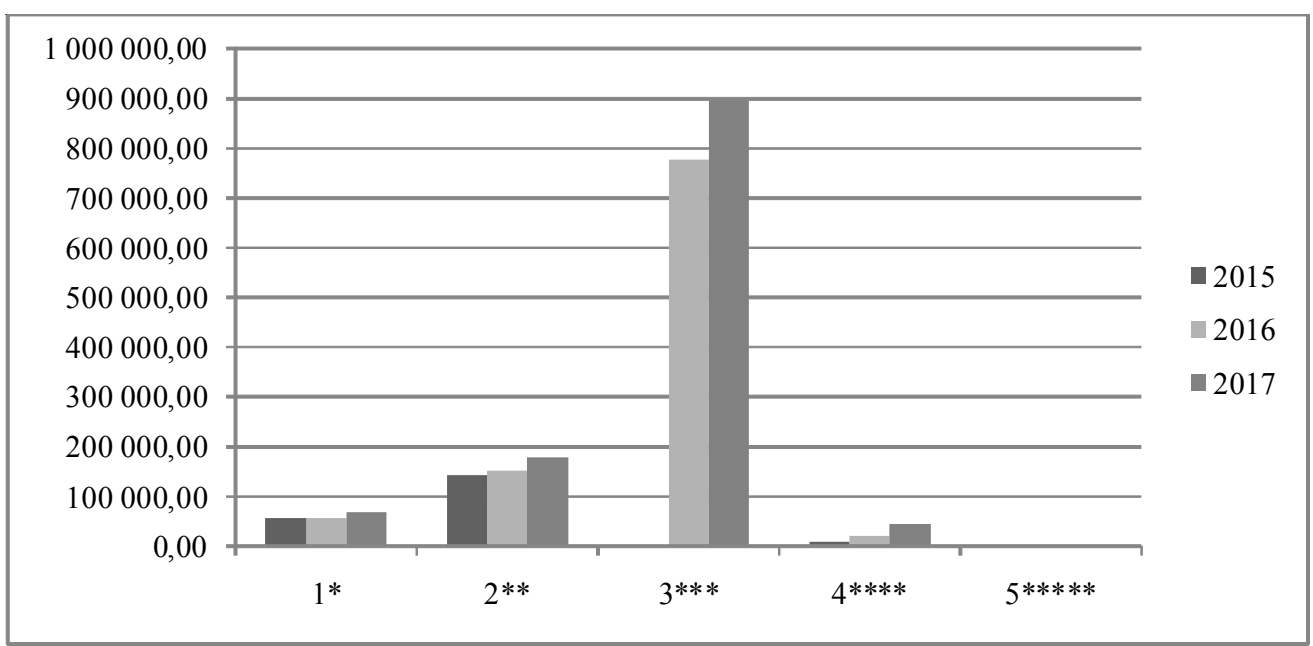

Рис. 3. Количество граждан (налогоплательщиков), применяющих налоговые вычеты в 2015-2017 гг.

Примечание. Составлено авторами по: [Федеральная налоговая служба]. 1 * - «количество налогоплательщиков, которым предоставлены социальные налоговые вычеты по суммам страховых взносов, уплаченным по договорам добровольного личного страхования, а также по договорам добровольного страхования супруга (супруги), родителей и (или) своих детей в возрасте до 18 лет» (единиц); 2 ** - «количество налогоплательщиков, которым предоставлены социальные налоговые вычеты, по суммам пенсионных и страховых взносов, уплаченным по договорам негосударственного пенсионного обеспечения, добровольного пенсионного страхования и добровольного страхования жизни, дополнительных страховых взносов на накопительную пенсию» (единиц); 3 *** - «количество налогоплательщиков, которым предоставлены имущественные налоговые вычеты по уплате процентов по займам (кредитам), направленным на приобретение объектов недвижимого имущества» (единиц); 4 **** - «количество налогоплательщиков, которым предоставлены инвестиционные налоговые вычеты в сумме денежных средств, внесенных налогоплательщиком в налоговом периоде на индивидуальный инвестиционный счет» (единиц); 5 ***** - «количество налогоплательщиков, которым предоставлены инвестиционные налоговые вычеты, принимаемые в уменьшение положительного финансового результата» (единиц). 
менение макроэкономических условий, геополитической обстановки, курса национальной валюты, институциональных изменений.

\section{СПИСОК ЛИТЕРАТУРЫ}

Агентство по страхованию вкладов. - Электрон текстовые дан. - Режим доступа: https:// www.asv.org.ru/. - Загл. с экрана.

Адвокатова, А. С. Взаимосвязь моделей поведения налогоплательщиков и налогового контроля / А. С. Адвокатова // Экономика. Налоги. Право. -2017 . - Т. 10, № 5. - С. 148-157.

Алиева, И. А. Финансовое поведение населения: теоретический аспект / И. А. Алиева // Вестник КРСУ. - 2016. - Т. 16, № 2. - С. 107-109.

Вылкова, Е. С. Экономические субъекты и государство: модели поведения при осуществлении управления налогообложением / Е. С. Вылкова, А. Л. Тарасевич // Известия Санкт-Петербургского государственного экономического университета. - 2017. - № 2 (104). - С. 44-50.

Галишникова, Е. В. Финансовое поведение населения: сберегать или тратить / Е. В. Галишникова // Государственный университет Минфина России. Финансовый журнал. - 2012. № 2 (12). - С. 133-140.

Галухин, А. В. К вопросу о налоговом поведении и повышении налоговой культуры налогоплательщиков / А. В. Галухин // Социальное пространство. - 2019. - № 1 (18). - С. 5-12.

Гондик, Н. Ю. Финансовое поведение населения: теоретические аспекты / Н. Ю. Гондик // Master's Journal. - 2014. - № 1. - C. 330-333.

Гришин, И. А. Поведенческий аспект в теории менеджмента и исследованиях экономики наноуровня / И. А. Гришин // Вестник Волгоградского государственного университета. Серия 3 , Экономика. Экология. - 2012. № 1 (20). - С. 156-163.

Иншаков, О. В. Экономическая генетика и наноэкономика / О. В. Иншаков. - Волгоград : Изд-во ВолГУ, 2007. - 92 с.

Клейнер, Г. Б. Наноэкономика и теория фирмы / Г. Б. Клейнер // Вестник ВГУ. Серия «Экономика и управление». - 2004. - № 2. - С. 99-123.

Мартынова, В. С. Налоговое поведение различных типов налогоплательщиков / В. С. Мартынова // Молодежь третьего тысячелетия : сб. науч. ст. XLII регион. студ. науч.-практ. конф. Омск, 2018. - С. 684-688.

Петенева, И. А. Влияние финансовых ожиданий на финансовое поведение населения России / И. А. Петенева // Ученые записки Алтайского филиала Российской академии народного хозяйства и государственной службы при Прези- денте Российской Федерации. - Барнаул : Алтайский филиал РАНХиГС, 2018. - С. 168-173.

Рейтинговое агентство «Эксперт РА». - Электрон. текстовые дан. - Режим доступа: https:// raexpert.ru/. - Загл. с экрана.

Федеральная налоговая служба : [офиц. сайт]. - Электрон. текстовые дан. - Режим доступа: https:// www.nalog.ru/rn34/. - Загл. с экрана.

Федеральная служба государственной статистики : [офиц. сайт]. - Электрон. текстовые дан. -Режим доступа: https://www.gks.ru/. - Загл. с экрана.

Фонд общественного мнения. - Электрон. текстовые дан. - Режим доступа: https://fom.ru/. Загл. с экрана.

Центральный банк Российской Федерации : [офиц. сайт]. - Электрон. текстовые дан. - Режим доступа: http://www.cbr.ru/. - Загл. с экрана.

\section{REFERENCES}

Agentstvo po strakhovaniyu vkladov [Agency on Insurance of Deposits]. URL: https://www. asv.org.ru/.

Advokatova A.S. Vzaimosvyaz modeley povedeniya nalogoplatelshchikov i nalogovogo kontrolya [Interrelation of Behavior Models of Taxpayers and Tax Control]. Ekonomika. Nalogi. Pravo, 2017, vol. 10, no. 5, pp. 148-157.

Alieva I.A. Finansovoe povedenie naseleniya: teoreticheskiy aspekt [Financial Behavior of the Population: Theoretical Aspect]. Vestnik KRSU, 2016, vol. 16, no. 2, pp. 107-109.

Vylkova E.S. Ekonomicheskie subyekty i gosudarstvo: modeli povedeniya pri osushchestvlenii upravleniya nalogooblozheniem [Economic Entities and the State: Models of Behavior in the Implementation of Tax Management]. Izvestiya Sankt-Peterburgskogo gosudarstvennogo ekonomicheskogo universiteta [Izvestiâ Sankt-Peterburgskogo gosudarstvennogo èkonomičeskogo universiteta], 2017, no. 2 (104), pp. 44-50.

Galishnikova E.V. Finansovoe povedenie naseleniya: sberegat ili tratit [Financial Behavior of the Population: Saving or Spending]. Gosudarstvennyy universitet Minfina Rossii. Finansovyy zhurnal, 2012, no. 2 (12), pp. 133-140.

Galukhin A.V. K voprosu o nalogovom povedenii i povyshenii nalogovoy kultury nalogoplatelshchikov [On the Issue of Tax Behavior and Improvement of Tax Culture of Taxpayers]. Sotsialnoe prostranstvo [Social Area ], 2019, no. 1 (18), pp. 5-12.

Gondik N.Yu. Finansovoe povedenie naseleniya: teoreticheskie aspekty [Financial Behavior of the Population: Theoretical Aspects]. Master's Journal, 2014, no. 1, pp. 330-333. 
Grishin I.A. Povedencheskiy aspekt v teorii menedzhmenta $\mathrm{i}$ issledovaniyakh ekonomiki nanourovnya [Behavioral Aspect of Management Theory and Studies of the Economy of the Nanoscale]. Vestnik Volgogradskogo gosudarstvennogo universiteta. Seriya 3, Ekonomika. Ekologiya [Science Journal of Volgograd State University. Global Economic System], 2012, no. 1 (20), pp. 156-163.

Inshakov O.V. Ekonomicheskaya genetika $i$ nanoekonomika [Economic Genetics and Nanoeconomics]. Volgograd, Izd-vo VolGU, $2007.92 \mathrm{p}$.

Kleyner G.B. Nanoekonomika i teoriya firmy [Nanoeconomics and the Theory of the Firm]. Vestnik VGU. Seriya «Ekonomika i upravlenie» [Proceedings of Voronezh State University. Series: Economics and Management], 2004, no. 2, pp. 99-123.

Martynova V.S. Nalogovoe povedenie razlichnykh tipov nalogoplatelshchikov [Tax Behavior of Different Types of Taxpayers]. Molodezh tretyego tysyacheletiya: sb. nauch. st. XLII region. stud. nauch.-prakt. konf. [The Youth of the Third Millennium. Collection of Scientific Articles of the $42^{\text {nd }}$ Regional Student
Scientific and Practical Conference]. Omsk, 2018, pp. 684-688.

Peteneva I.A. Vliyanie finansovykh ozhidaniy na finansovoe povedenie naseleniya Rossii [The Impact of Financial Expectations on the Financial Behavior of the Russian Population]. Uchenye zapiski Altayskogo filiala Rossiyskoy akademii narodnogo khozyaystva i gosudarstvennoy sluzhby pri Prezidente Rossiyskoy Federatsii [Scientific Notes of the Altai Branch of Russian Presidential Academy of National Economy and Public Administration]. Barnaul, Altayskiy filial RANKhiGS, 2018, pp. 168-173.

Reytingovoe agentstvo «Ekspert RA» [Rating Agency "Expert RA"]. URL: https://raexpert.ru.

Federalnaya nalogovaya sluzhba: [ofits. sayt] [Federal Tax Service. Official Website]. URL: https://www.nalog.ru/rn34.

Federalnaya sluzhba gosudarstvennoy statistiki: [ofits. sayt] [Federal State Statistics Service. Official Website]. URL: https://www.gks.ru/.

Fond obshchestvennogo mneniya [Public Opinion Foundation]. URL: https://fom.ru.

Tsentralnyy bank Rossiyskoy Federatsii: [ofits. sayt] [Central Bank of the Russian Federation. Official Website]. URL: http://www.cbr.ru.

\section{Information About the Authors}

Natalia V. Gorshkova, Doctor of Sciences (Economics), Associate Professor, Head of the Department of Finance Theory, Credit and Taxation, Volgograd State University, Prosp. Universitetsky, 100, 400062 Volgograd, Russian Federation, GorshkovaNV@volsu.ru, https://orcid.org/0000-0003-0586-9509

Victoria M. Ksenda, Candidate of Sciences (Economics), Associate Professor, Department of Finance Theory, Credit and Taxation, Volgograd State University, Prosp. Universitetsky, 100, 400062 Volgograd, Russian Federation, KsendaVM@volsu.ru, https://orcid.org/0000-0002-4634-0698

\section{Информация об авторах}

Наталья Валерьевна Горшкова, доктор экономических наук, доцент, заведующая кафедрой теории финансов, кредита и налогообложения, Волгоградский государственный университет, просп. Университетский, 100, 400062 г. Волгоград, Российская Федерация, GorshkovaNV@volsu.ru, https://orcid.org/0000-0003-0586-9509

Виктория Михайловна Ксенда, кандидат экономических наук, доцент кафедры теории финансов, кредита и налогообложения, Волгоградский государственный университет, просп. Университетский, 100, 400062 г. Волгоград, Российская Федерация, KsendaVM@volsu.ru, https://orcid.org/0000-0002-4634-0698 